\title{
免疫の老化：感染防御と栄養介入の最前線
}

\author{
丸山光生, ${ }^{*}, a, b$ 坂本明彦, ${ }^{a}$ 森田悠治, ${ }^{c}$ 高岡晃教 ${ }^{d}$
}

\section{Immunosenescence: The Forefront of Infection and Trophic Control}

\begin{abstract}
Mitsuo Maruyama, ${ }^{*, a, b}$ Akihiko Sakamoto, ${ }^{a}$ Yuji Morita, ${ }^{c}$ and Akinori Takaoka ${ }^{d}$
${ }^{a}$ Department of Mechanism of Aging, National Center for Geriatrics and Gerontology; 7-430 Morioka-cho, Obu, Aichi 474-8511, Japan: ${ }^{b}$ Department of Aging Research, Nagoya University Graduate School of Medicine; 65 Tsurumai-cho,

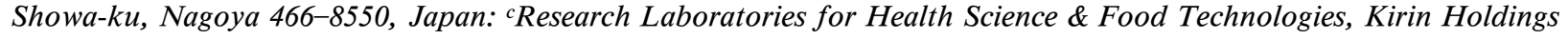
Company, Limited; 1-13-5 Fukuura, Kanazawa-ku, Yokohama 236-0004, Japan: and Division of Signaling in Cancer and Immunology, Institute for Genetic Medicine, Hokkaido University; Kita-15, Nishi-7, Kita-ku, Sapporo 060-0815, Japan.
\end{abstract}

(Received August 2, 2019)

\begin{abstract}
Recently, aging is becoming an important social problem in many developed countries including Japan. It is socially and universally important to unveil the impact of aging and extend healthy life expectancy. Here we show our recent finding that dedicator of cytokinesis 11 (DOCK11, also known as Zizimin2) may be involved in immunosenescence of B cells. DOCK11 was identified as a guanine nucleotide exchange factor for a small GTPase called cell division cycle 42 . Expression of DOCK11 is restricted to lymphoid tissues, and becomes downregulated with age. Thus we examined the involvement of DOCK11 in immunosenescence of B-1a B cells as an example. B-1a cells are the main source of antibodies at steady state, and function as the first line of defense against infection. Although DOCK11 was expressed by B-1a cells, the expression levels declined with age. Furthermore, production of anti-pneumococcal immunoglobulin M antibodies was suppressed in aged mice, and was recovered by adoptive transfer with B-1a cells in a DOCK11-dependent manner. Thus DOCK11 may be involved in immunosenescence of B-1a cells.
\end{abstract}

Key words - B-1a B cell; dedicator of cytokinesis 11; immunosenescence

\section{はじめに}

近年, 日本を含む多くの先進国で高齢化が顕在化 している．高齢者では組織の恒常性と再生能力が低 下するため, がんや心疾患, 認知症, 感染症などの 老年疾患に注意する必要がある。そのため，これら の疾患における加齢の影響を明らかにし，予防につ なげることは重要である.

例えば，高齢者の感染症対策は重要な課題であ り，なかでも肺炎は高齢者で重篤化し易い感染症で あるため, 65 歳以上の高齢者を対象にワクチンの

${ }^{a}$ 国立長寿医療研究センター老化機構研究部 (₹4748511 愛知県大府市森岡町 7-430), $b$ 名古屋大学大学院 医学系研究科老化基礎科学（广466-8550 名古屋市昭和 区鶴舞町 65), ${ }^{c}$ キリンホールディングス株式会社健康 技術研究所（二236-0004 横浜市金沢区福浦 1-13-5), $d$ 北海道大学遺伝子病制御研究所分子生体防御分野 （厂060-0815 札幌市北区北 15 西 7）

*e-mail: michan@ncgg.go.jp 本総説は, 日本薬学会第 139 年会シンポジウム S17 で 発表した内容を中心に記述したものである.
定期接種が行われている。しかし，肺炎球菌ワクチ ンを始めとして，ワクチンの効果は高齢者で限定的 なことが多い，その原因として，免疫細胞が老化し て，本来の機能が失われることが考えられている. そのため, このような免疫老化のしくみを明らかに し, 高齢者の肺炎予防へと応用することが重要であ る. 本稿では，免疫老化に関するわれわれの研究成 果の一例を紹介する. ${ }^{1,2}$

\section{DOCK11 の発現と機能}

$\mathrm{B}$ 細胞はワクチンの接種や細菌・ウイルスの感染 により活性化し，抗体産生細胞やメモリー B 細胞 へ分化する.これらの細胞は, 長期的に生体を防御 するのに重要な免疫細胞である。㞷われわれは, 夕 ンパク質抗原の投与により活性化したマウスの B 細胞から dedicator of cytokinesis 11 (Dock11 又は Zizimin2）遺伝子をクローニングした. ${ }^{4)}$ DOCK11 は，グアニンヌクレオチド交換因子として小分子 GTP 加水分解酵素の cell division cycle 42 (CDC42) を活性化し, ${ }^{4)}$ 細胞骨格の再構成を誘導した（Fig. 


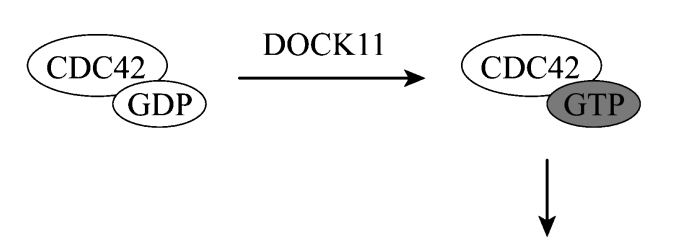

Cytoskeletal reorganization

Fig. 1. DOCK11 as a Guanine Nucleotide Exchange Factor for $\mathrm{CDC} 42$

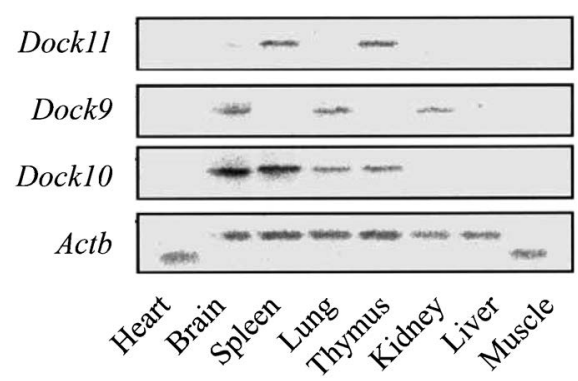

Fig. 2. Specific Expression of DOCK11 by Lymphoid Tissues Tissue distributions of the indicated Zizimin family proteins were determined by Northern blotting, using tissues from C57BL/6 mice.

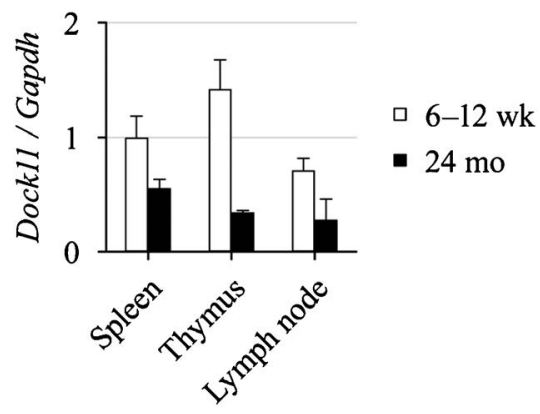

Fig. 3. Age-dependent Decline in Expression Levels of DOCK 11

Expression levels of DOCK11 were determined by quantitative reverse transcription-polymerase chain reaction, using tissues from C57BL/6 mice at the indicated ages. Error bars indicate S.D.

1).5)また, DOCK11 は他の Zizimin ファミリータ ンパク質と違って，免疫組織特異的に発現している ことが分かった (Fig. 2).4-7) そこで, DOCK11の 発現量を 6-12 週齢と 24 カ月齢の C57BL/6 マウス で比較した。その結果, DOCK11 の発現量が加齢 とともに低下することが分かった（Fig. 3).5,6)この ように，老齢マウスの免疫組織で DOCK11 の発現 量が低下していたことから, DOCK11 と免疫老化 の関連が予想された。
A

B-1a from

WT vs DKO

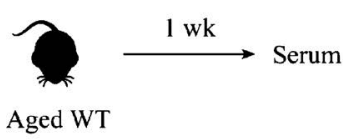

B
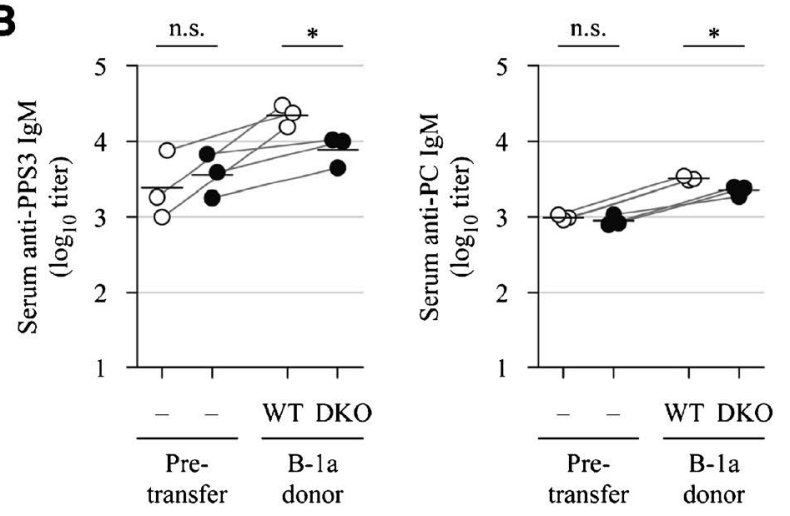

Fig. 4. DOCK11-dependent Production of Anti-pneumococcal IgM in Aged Mice

(A) Strategy to rescue the lower serum levels of IgM in aged mice (older than 18 months) by adoptive transfer of 2- to 4-month-old young B-1a cells. WT, wild-type; DKO, Dock11/10 double knockout. (B) Serum levels of IgM before and 1 week after transfer of the indicated B-1a cells, as measured by ELISA. Data from the same recipient mice are connected with lines (WT, $n=3$; DKO, $n=3$ ). Bars represent the mean. ${ }^{*} p<0.05$ (Welch's $t$-test). PPS3, pneumococcal polysaccharide of type 3; PC, phosphorylcholine; n.s., not significant.

\section{B-1a 細胞の老化における DOCK11 の関与}

$\mathrm{B}-1 \mathrm{a}$ 細胞は腹腔に存在する $\mathrm{B}$ 細胞で，平常時の 免疫グロブリン M (immunoglobulin M; IgM）抗 体の供給源とされている。近年，加齢に伴って感染 防御に係わる IgM の量が減ることが分かってきた が，そのしくみはよく分かっていなかった. ${ }^{8)}$ そこ で，われわれは B-1a 細胞における DOCK11 の機 能に着目し, IgM 産生への関与を調べた. ${ }^{1)}$

C57BL/6 マウスを自然に加齢させ，フローサイ トメトリーで腹腔の B-1a 細胞を分離した。肺炎球 菌表面の多糖や脂質を例とし，これらに対する $\operatorname{IgM}$ の産生細胞数を調べた。 2-4 カ月齢と 18 力月 齢以上のマウスを比較した結果, 18 力月齢以上の マウスの方が肺炎球菌表面の多糖や脂質に対する $\operatorname{IgM}$ の産生細胞数が少ないことが分かった。そこ で, B-1a 細胞での Dock11 の発現を定量 PCR で調 べた。その結果，18 カ月齢以上のマウスの方が Dock11 の発現量が低いことが分かった.

B-1a 細胞には DOCK11 だけでなく DOCK10 も 発現している。 DOCK11，DOCK10 はいずれも 
Anti-pneumococcal IgM

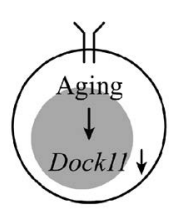

B-1a cell
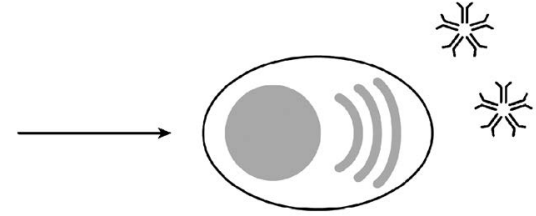

IgM-producing cell $\downarrow$
Fig. 5. Involvement of DOCK11 in Immunosenescence of B1a Cells

CDC42 を活性化することから，Dock11 とDock10 のダブルノックアウトマウスを作製した。腹腔の B-1a 細胞を分離し, 肺炎球菌表面の多糖や脂質に 対する IgM の産生細胞数を調べた。 その結果,

Dock11/10 ダブルノックアウトマウスで肺炎球菌 表面の多糖や脂質に対する IgM の産生細胞数が少 ないことが分かった。また，Dock11/10 ダブル ノックアウトマウスの腹腔内に野生型マウス由来の B-1a 細胞を移植した。その結果，肺炎球菌表面の 多糖や脂質に対する IgM の血中濃度が，野生型マ ウスと同等に回復した。これらのことから，

DOCK11 が肺炎球菌の感染防御に係わる IgM の産 生に係わることが分かった.

そこで，老齢マウスの腹腔内に野生型又は Dock11/10 ダブルノックアウトマウス由来の B-1a 細胞を移植した。 その結果，老齢マウスの腹腔内に Dock11/10 ダブルノックアウトマウス由来の B-1a 細胞を移植しても，野生型マウス由来の B-1a 細胞 を移植したときほど，肺炎球菌表面の多糖や脂質に 対する IgM の産生を回復できないことが分かった (Fig. 4).

おわりに

本研究により，加齢に伴って B-1a 細胞で DOCK11 の発現量が低下し, 肺炎球菌の感染防御
に係わる IgM の産生細胞数が減少することが示さ れた（Fig. 5)。このような基礎老化研究が臨床に 応用され，健康長寿社会の原動力となることを期待 する.

謝辞本研究報告は, 国立長寿医療研究セン 夕一長寿医療研究開発費 (28-39) と北海道大学遺 伝子病制御研究所共同研究費による研究成果である.

利益相反＼cjkstart開示すべき利益相反はない.

\section{REFERENCES}

1) Sakamoto A., Matsuda T., Kawaguchi K., Takaoka A., Maruyama M., Int. Immunol., 29, 431-438 (2017).

2) Morita Y., Jounai K., Sakamoto A., Tomita Y., Sugihara Y., Suzuki H., Ohshio K., Otake M., Fujiwara D., Kanauchi O., Maruyama M., Aging, 10, 2723-2740 (2018) .

3) Maruyama M., Lam K. P., Rajewsky K., Nature, 407, 636-642 (2000).

4) Nishikimi A., Meller N., Uekawa N., Isobe K., Schwartz M. A., Maruyama M., FEBS Lett., 579, 1039-1046 (2005).

5) Sakabe I., Asai A., Iijima J., Maruyama M., Immun. Ageing, 11, 2 (2012).

6) Jia Y., Sakabe I., Matsuda T., Hayakawa T., Maruyama M., Nagoya J. Med. Sci., 74, 303311 (2012).

7) Matsuda T., Yanase S., Takaoka A., Maruyama M., Immun. Ageing, 12, 1 (2015).

8) Holodick N. E., Vizconde T., Hopkins T. J., Rothstein T. L., J. Immunol., 196, 4348-4357 (2016) . 